\title{
COMPARATIVE ANALYSIS OF TAX CAPACITY IN REGIONS OF RUSSIA
}

\author{
Lyudmila PARFENOVA ${ }^{\mathrm{a}}$, Andrey PUGACHEV ${ }^{\mathrm{a}}$, Askoldas PODVIEZKO ${ }^{\mathrm{b}}$ \\ ${ }^{a}$ P. G. Demidov Yaroslavl State University, Yaroslavl, Sowetskaya 14, Russia \\ ${ }^{b}$ Vilnius Gediminas Technical University, Lithuania, Vilnius \\ ${ }^{b}$ Mykolas Romeris University, Lithuania, Vilnius
}

Received 9 December 2015; accepted 10 April 2016

\begin{abstract}
Influence of tax policy of the state and its regions is vital for country's economy; it is the major source of allocation of expenditure obligations of tax capacity on the sub-federal level. The purpose of this research is to estimate the predictive tax capacity of regions (TCR) and to create a comparative evaluation of regions on the basis of criteria, which are influencing the tax capacity using different methods of evaluation: multiple criteria decision-making (MCDM) and econometric methods. Criteria, which are having the greatest influence on the TCR, were identified on the basis of empirical data both using regression analysis and expert estimates. The objective, subjective, and cumulative weights have been calculated, the degree of concordance of expert opinions was gauged. The comparative evaluation of the TCR in four regions of Russia in 2000-2012 was performed on the basis of MCDM methods.
\end{abstract}

Keywords: tax capacity, region, correlation and regression analysis, experts, concordance, MCDM.

JEL Classification: C25, C44, C53, C58, G17, H21.

\section{Introduction}

In the second half of the twentieth century problems of tax federalism and intergovernmental fiscal relations formed a new branch of economic study. The topic is currently relevant for many countries. A variety of research on tax and budget relations can be found all over the world (Burman, Phaup 2011; Ong Lynette 2011; Walia 2013; Naik 2013; Gilardi, Wasserfallen 2014; Skackauskiene 2013; Skackauskiene, Tuncikiene 2012; Bivainis, Skackauskiene 2008). There still is a need to estimate an adequate amount of expenditure obligations of tax capacity on the sub-federal level. Purpose and novelty of this research is related to the need to create an effective tax system of fiscal federalism, an intergovern-

Corresponding author Askoldas Podviezko

E-mail: askoldas@gmail.com 
mental system of aligning reduction of inequality among regions, and development of the financial policy at the level of the federal center and regional authorities.

The purpose of this study is to evaluate predictive capability of tax capacity of region (TCR) and to carry out comparative assessment of regions on the basis of criteria, which influence the tax capacity, using different econometric methods.

To achieve this goal the following tasks were implemented:

- a set of criteria making influence on the TCR was elicited from the literature;

- criteria, which make substantial influence on the TCR were identified in two ways: based on empirical data by using regression analysis, and on expert evaluation;

- relative degree of the influence of the criteria in terms of weights was estimated, based on expert opinions;

- concordance of opinions of the experts was gauged;

- tax capacity in different regions of Russia was evaluated using multiple criteria decision-making (MCDM) methods; the regions were compared;

- results obtained from regression analysis and MCDM methods were compared.

\section{The economic essence of the tax capacity of the region}

Importance of tax policy proved to have a considerable effect on growth of certain sectors of economy, sometimes even devastating effect (Nasulea 2014). Predictable tax policy makes economic environment much more favourable for investors (Savrina 2013). Closely related tax capacity topic is popular subject of research among scientists. An incomplete list of examples could be the following: Bird, Martinez-Vazquez (2008), Barro (1986), Le et al. (2012), Bird et al. (2004), Schratzenstaller (2011), etc. Approaches of defining the essence of tax capacity vary depending on the context of a particular paper. Thus, in "Tax Capacity and Tax Effort: Extended Cross - Country Analysis from 1994 to 2009” (Le et al. 2012) we derive that tax capacity primarily depends on such a dynamic characteristic as tax-toGDP ratio, which is estimated empirically observing country's specific macroeconomic, demographic, and institutional features. Barro (1986) in "State Fiscal Capacity Measures: A Theoretical Critique" characterizes tax capacity as the ability of the administrative and territorial unit to receive tax revenues from their own sources, regardless of the existing level of the fiscal influence.

The outlined examples demonstrate that the TCR could be considered both as being dependent on external criteria as is demonstrated by the former example, while the theoretical definition provided in the latter example suggests that the TCR stems from the internal tax-collection potential.

The subject of determining the tax potential, and in particular the TCR, commenced to develop along with formation of the modern Russian model of fiscal federalism in the early 90s of the last century. The lack of regulatory definitions of the TCR in the Russian legislation is in fact generating (instead of impairing) substantial efforts in developing concepts of the TCR. Presently, the following major approaches can be discerned: resource, fiscal, and mixed approaches (Parfenova, Pugachev 2013). 
The resource approach views the tax capacity as a resource of the budget income, accumulated from tax payments (Bushinsky 2009; Karataev 2010; Matrusov 1995; Osipov 2008; etc.)

The fiscal approach views the TCR as being a maximizing source of all possible tax payments to the budget (e.g. Panskov 2013).

Within the framework of the mixed approach, the tax capacity is understood as a maximizing amount of tax revenue that could be collected in a territory of a federal subject of the Russian Federation within a specified period, provided that all available resources in the region were used (Tolstaya 2010; Krasnitsky 2009).

In general, the tax capacity of the region can be considered as a compound of two components: budgetary and fiscal. It is the maximizing amount of budget revenues, which is potentially accumulated within a specified period of time by mediation of tax authorities as taxes, levies and other mandatory payments of corporates and individuals as is determined by the current legislation within a territory, in accordance with the tax policy of the State and the level of economic development of the region (Parfenova, Pugachev 2013).

The model of tax policy within the Federation, and intergovernmental fiscal relations determine the TCR. Treatment of the TCR within such models for the purpose of tax planning and forecasting requires invention of tools, which quantify the TCR. And quantitative evaluation of the TCR requires to identify a set of criteria, which make effect on the TCR.

\section{A study of criteria influencing the tax capacity of the region}

Criteria, which make effect on the TCR within a separate tax system can be elicited from the historical data, which describe structure of tax income of the budget, taking into consideration the tax base of the income. Take the Yaroslavl region, the region in the north of European Russia, the Central Federal District, as an example. The major components of the total tax capacity of the Yaroslavl region (including revenues to budgets of all levels of budgetary system) in 2013 were the excise tax $(46 \%)$, the tax on personal income (PIT) (17\%), value added tax (hereinafter VAT) (15\%), and corporate income tax (11\%). The structure of the total tax capacity of the Yaroslavl region in 2013 is presented in Figure 1.

It follows from collected empirical data that the tax capacity of the Yaroslavl region is formed primarily by 4 types of tax, which in total make $89 \%$. Major criteria effecting the TCR other conditions equal, are found among entries recorded in the fiscal database of taxes formed in accordance with the Tax Code of the Russian Federation, are as follows: the gross regional

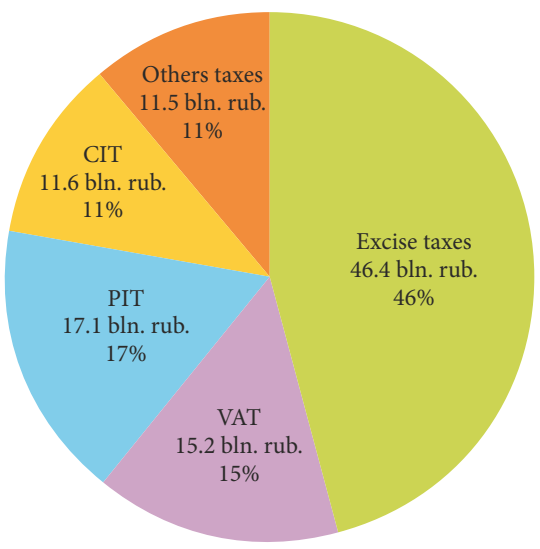

Fig. 1. Structure of tax capacity in the Yaroslavl region, 2013 
product (for indirect taxes), net income after deduction of social security contributions (personal income tax), and corporate profit.

There is a large range of research performed both by Russian and non-Russian authors, where criteria determining the TCR are defined and analyzed. The following authors could be considered as representatives of the research in the field: R. M. Bird, M. N. Eltony, J. R. Lotz, E. Morss, K. Shin, J. G. Stotsky, A. WoldeMariam, E. S. Vylkova, A. S. Karataev, O. A. Mironova, V. G. Panskov, F. F. Hanafheev, and others. It would be interesting to extend the research to other types of financial systems (Podviezko 2015). Summary of found in the literature criteria influencing the TCR is provided in Table 1.

Table 1. Criteria determining the TCR

\begin{tabular}{|c|c|c|}
\hline № & Criteria & Authors \\
\hline 1 & Gross regional product (GRP) & $\begin{array}{l}\text { Bird, Martinez-Vazquez 2008; Eltony 2002; Lotz, Morss } \\
\text { 1970; Stotsky, WoldeMariam 1997; Hanafeev 2008; } \\
\text { Parfenova et al. } 2013\end{array}$ \\
\hline 2 & $\begin{array}{l}\text { The ratio of exports or imports to } \\
\text { the GRP }\end{array}$ & Bird, Martinez-Vazquez 2008 \\
\hline 3 & Inflation & Karataev 2010; Vylkova, Pozov 2013 \\
\hline 4 & Urals crude oil price & Panskov 2013; Vylkova, Pozov 2013 \\
\hline 5 & $\begin{array}{l}\text { Geographic and economic } \\
\text { location of the region }\end{array}$ & $\begin{array}{l}\text { Mironova, Hanafeev 2013; Popenkov 2006; } \\
\text { Kolesnikova } 2004\end{array}$ \\
\hline 6 & Location of productive forces & $\begin{array}{l}\text { Bird, Martinez-Vazquez 2008; Shin 1969; Mironova, } \\
\text { Hanafeev 2013; Vylkova, Pozov 2013; Kuznetsova 2007; } \\
\text { Popenkov 2006; Kolesnikova 2004; Hanafeev } 2008\end{array}$ \\
\hline 7 & The scale of the shadow economy & $\begin{array}{l}\text { Bird, Martinez-Vazquez 2008; Mironova, Hanafeev 2013; } \\
\text { Panskov } 2013\end{array}$ \\
\hline 8 & Investment climate & Panskov 2013; Karataev 2010; Kuznetsova 2007 \\
\hline 9 & Quality of tax administration & $\begin{array}{l}\text { Shin 1969; Mironova, Hanafeev 2013; Karataev 2010; } \\
\text { Kuznetsova 2007; Vylkova, Pozov } 2013\end{array}$ \\
\hline 10 & $\begin{array}{l}\text { Demographic characteristics of } \\
\text { the region }\end{array}$ & Bird, Martinez-Vazquez 2008 \\
\hline
\end{tabular}

Thus, we can identify the following criteria, which determine the TCR, as the most popular among researchers: the GRP, economic and geographic location of the region, location of productive forces, quality of tax administration, investment climate, and the scale of the shadow economy. These factors characterize the scale of production, the resource base, investment attractiveness of a region, consequently being components of tax base.

Naturally, magnitude of the shadow economy undermines the TCR. In Russia the shadow economy was and still steadily remains considerable. In accordance to the latest research performed by OAO Sberbank (2014) the shadow economy was a considerable factor in 2014 as it made up $20-35 \%$ of the total economy. Since the shadow economy is currently regarded to be rather similar in the regions investigated until some more precise 
research will have appeared in the literature, the shadow economy factor was not included into the research.

Besides the factor of the shadow economy the following factors were not included into the research, because in the period of investigation such factors in the literature were often treated as inconsiderable: exports and imports to the GDP, inflation, Urals crude oil price, demographic factors. Negligible influence of the latter factors is explained by the stable balance of payments of Russia; absence of the Olivera-Tanzi effect partly because of reduction of inflation since 2000, which in accordance with the information provided by the Federal State Statistics Service of the Russian Federation became 106-114\% after 110-233\% in the 90s; the exchange crude oil price fluctuations were outweighed by increase of oil production, which also somewhat stimulated the TCR, stabilization of population of Russia.

It is important to note that currently the set of criteria affecting tax capacity is mainly being identified using empirical methods. We are going to use regression analysis in order to find most affecting tax capacity criteria in the Yaroslavl region within the Central Federal District.

\section{Eliciting a set of criteria effecting the tax capacity of the region, with the use of regression analysis}

In order to determine the set of criteria, that effect the tax capacity of the Yaroslavl region we used the database of the Federal State Statistics Service (Rosstat), and identified popular approaches in the literature. The set of criteria is listed in Table 2.

Table 2. Criteria determining the TCR

\begin{tabular}{|c|c|c|}
\hline Criterion & Abbreviation & Comment \\
\hline Gross regional product & GRP & $\begin{array}{l}\text { Includes the tax base for the VAT and excise duties, } \\
\text { special tax regimes, corporate income tax and reflects } \\
\text { the overall dynamics of the regional economy. It is } \\
\text { reflected in six sources as a criterion effecting the TCR. }\end{array}$ \\
\hline $\begin{array}{l}\text { Personal income excluding } \\
\text { social security contributions }\end{array}$ & PILSC & Includes tax base for personal income tax. \\
\hline Corporate profit & $\mathrm{CP}$ & Includes tax base for corporate income tax. \\
\hline Net corporate profit & FIS & Makes the tax base for corporate income tax. \\
\hline $\begin{array}{l}\text { The number of occupied } \\
\text { employees }\end{array}$ & FS & $\begin{array}{l}\text { Reflects the overall dynamics of the economy of } \\
\text { the region and is connected with the criterion of } \\
\text { productive forces. }\end{array}$ \\
\hline Fixed asset investment & FAI & $\begin{array}{l}\text { Reflects dynamics and forms of the tax base for } \\
\text { property tax; is associated with the investment climate } \\
\text { in the region. }\end{array}$ \\
\hline Foreign investments & FDI & $\begin{array}{l}\text { Reflects the general dynamics of the economy of the } \\
\text { region and is connected with the investment climate in } \\
\text { the region. }\end{array}$ \\
\hline Retail trade turnover & RTT & $\begin{array}{l}\text { Includes the tax base for the VAT, excise duties and } \\
\text { special tax regimes of trade organizations. }\end{array}$ \\
\hline
\end{tabular}


Prior to using regression analysis for the purpose of identifying the criteria that determine the TCR, statistical data of the Central Federal District was collected. Absolute values were transformed to relative ones using corresponding consumer price indices for the purpose of elimination of autocorrelation, by the following formula:

$$
a_{i i}=\frac{a_{i}}{a_{i-1} C P I_{i}},
$$

where $a_{i}$ is the value of the index in the $i$-th year, $C P I_{i}$ is the Consumer Price Index in the $i$-th year.

In order to calculate the TCR in any given year, data on growth of debt on taxes and duties of the budget system in the relevant year have been added to the largest collection of taxes, fees and other mandatory payments. The statistical data for all regions of the Central Federal District of Russia are presented in Table 3.

Table 3. Growth rate of criteria, which determine tax capacity of Central Federal District regions in $2010-2011, \%$

\begin{tabular}{|c|c|c|c|c|c|c|c|c|c|}
\hline Region & TCR & GRP & FIS & PILSC & FS & RTT & FDI & FAI & $\mathrm{CP}$ \\
\hline \multicolumn{10}{|c|}{2010} \\
\hline Belgorodsk & 127.03 & 122.14 & 160.21 & 104.74 & 100.66 & 110.17 & 6832.89 & 130.19 & 153.95 \\
\hline Bryansk & 155.49 & 117.88 & 239.19 & 109.62 & 98.18 & 115.79 & 170.13 & 109.44 & 224.96 \\
\hline Vladimir & 107.35 & 110.91 & 114.97 & 104.37 & 100.09 & 114.06 & 64.18 & 109.53 & 119.65 \\
\hline Voronezh & 114.71 & 130.65 & 300 & 111.54 & 100.06 & 117.83 & 273.09 & 110.54 & 139 \\
\hline Ivanovo & 106.51 & 121.74 & 10.93 & 112.05 & 135.06 & 120.39 & 369.03 & 97.27 & 135.06 \\
\hline Kaluga & 114.13 & 118.84 & 131.06 & 106.22 & 99.98 & 112.77 & 73.08 & 86.95 & 128.5 \\
\hline Kostroma & 104.4 & 114.26 & 94.11 & 103.2 & 97.98 & 110.85 & 231.79 & 95.24 & 97.17 \\
\hline Kursk & 98.93 & 115.05 & 266.5 & 105.74 & 101.01 & 112.63 & 298.86 & 119.89 & 240.99 \\
\hline Lipeck & 94.43 & 107.19 & 92.29 & 99.61 & 99.93 & 112.4 & 59.27 & 110.73 & 96.26 \\
\hline Moscow & 111.36 & 112.1 & 91.68 & 100.28 & 101.45 & 108.32 & 174.79 & 108.14 & 106.89 \\
\hline Moscow dist. & 106.46 & 118.02 & 105.04 & 107.52 & 100.35 & 112.27 & 83.14 & 94.82 & 99.23 \\
\hline Orlyol & 109.02 & 120.81 & 109.62 & 107.13 & 100.23 & 111.13 & 17.58 & 159.87 & 114.28 \\
\hline Ryazan & 118.25 & 114.62 & 84.17 & 98.52 & 99.92 & 109.96 & 98.26 & 123.5 & 86.22 \\
\hline Smolensk & 106.17 & 115.49 & 142.52 & 102.65 & 100 & 105.08 & 115.26 & 116.56 & 132.61 \\
\hline Tambov & 97.5 & 124.3 & 88.95 & 104.95 & 100.1 & 110.91 & 75.83 & 115.85 & 102.05 \\
\hline Tver & 96.35 & 110.22 & 100.98 & 100.57 & 99.66 & 106.6 & 115.98 & 97.1 & 114.74 \\
\hline Tula & 118.87 & 108.67 & 107.46 & 105.33 & 99.96 & 107.18 & 130.54 & 96 & 118.04 \\
\hline Yaroslavl & 115.32 & 114.84 & 70.22 & 99.23 & 99.08 & 114.62 & 85.35 & 91.21 & 84.34 \\
\hline \multicolumn{10}{|c|}{2011} \\
\hline Belgorodsk & 138.7 & 119.69 & 253.39 & 107.8 & 100.07 & 104.68 & 87.92 & 120.83 & 211051 \\
\hline Bryansk & 64.57 & 103.13 & 81.86 & 100.59 & 98.2 & 106.86 & 64.58 & 141.35 & 78.44 \\
\hline Vladimir & 104.09 & 107.19 & 149.65 & 103.87 & 100.03 & 104.91 & 131.21 & 88.5 & 120.41 \\
\hline Voronezh & 111.88 & 100.98 & 60.64 & 104.76 & 99.91 & 108 & 132.4 & 129.33 & 127.12 \\
\hline Ivanovo & 107.24 & 100.54 & 107.34 & 101.32 & 99.88 & 106.97 & 72.15 & 83.56 & 97.66 \\
\hline
\end{tabular}


End of Table 3

\begin{tabular}{lccccccccc}
\hline \multicolumn{1}{c}{ Region } & TCR & GRP & FIS & PILSC & FS & RTT & FDI & FAI & CP \\
\hline Kaluga & 143.68 & 109.79 & 204.85 & 101.69 & 99.85 & 106.98 & 97.13 & 113.76 & 142.31 \\
\hline Kostroma & 100.4 & 105.45 & 48842.8 & 108.18 & 101.36 & 109.88 & 47.46 & 120.13 & 142.83 \\
\hline Kursk & 129.29 & 108.77 & 332.12 & 99.25 & 98.81 & 102.62 & 608.83 & 102.21 & 191.63 \\
\hline Lipeck & 92.97 & 103.01 & 129.15 & 95.86 & 99.85 & 103.36 & 236.49 & 110.45 & 120.94 \\
\hline Moscow & 106.14 & 108.06 & 127.67 & 99.97 & 100.3 & 104.53 & 146.82 & 90.47 & 109.84 \\
\hline Moscow dist. & 108.81 & 109.48 & 161.91 & 101.62 & 100.74 & 105.32 & 126.93 & 95.45 & 130.96 \\
\hline Orlyol & 109.68 & 103.72 & 366.42 & 105.23 & 98.81 & 107.44 & 2629.97 & 97.21 & 145.54 \\
\hline Ryazan & 114.43 & 103.62 & 169.48 & 101.72 & 101.19 & 100.45 & 102.96 & 97.98 & 130.47 \\
\hline Smolensk & 106.38 & 108.23 & 151.45 & 100.27 & 100.24 & 104.55 & 104.96 & 128.3 & 99.84 \\
\hline Tambov & 100.11 & 91.95 & 96.66 & 98.24 & 100.6 & 98.65 & 450.86 & 99.19 & 87.29 \\
\hline Tver & 104.75 & 100.82 & 101.39 & 100.16 & 98.73 & 103.76 & 46.82 & 107.52 & 104.65 \\
\hline Tula & 98.1 & 100.24 & 139.3 & 99.56 & 101.07 & 107.94 & 67.98 & 105.6 & 105.94 \\
\hline Yaroslavl & 109.77 & 99.67 & -850.1 & 90.59 & 98.13 & 102.35 & 42.87 & 114.02 & 156.13 \\
\hline
\end{tabular}

For the purpose of making analysis of the influence of each criterion on the targeting value of the TCR the database for 2010-2011, which reflects dynamics of the influencing criteria for all regions of the Central Federal District, was formed. A weak correlation between criteria and the TCR or the absence of such was revealed on the basis of regression analysis (Table 4 ). The oddity could be explained by the use of statistics for 2 years, which has led to the analysis of accounting tactical features of two different periods. In order to eliminate the described effect, a similar analysis for the Central Federal District was carried out as well, but only for 2011. Results were the same as in the analysis of the criteria for 2010-2011 (Table 4).

Table 4. Results of correlation and regression analysis of the relationship between the performance criteria and the tax capacity of the Central Federal District regions, 2010-2011

\begin{tabular}{ccccc}
\hline Criteria & \multicolumn{2}{c}{ Data analysis $2010-2011(v=34)$} & \multicolumn{2}{c}{ Data analysis $2011(v=16)$} \\
\cline { 2 - 5 } GRP & $\begin{array}{c}\text { The coefficient of } \\
\text { determination }\left(\mathrm{R}^{2}\right)\end{array}$ & $\begin{array}{c}\text { Statistical significance } \\
(\mathrm{t}-\mathrm{t} \text {-test })\end{array}$ & $\begin{array}{c}\text { The coefficient of } \\
\text { determination }\left(\mathrm{R}^{2}\right)\end{array}$ & $\begin{array}{c}\text { Statistical } \\
\text { significance }\left(\mathrm{R}^{2}\right)\end{array}$ \\
\hline PILSC & 0.111 & 0.01 & 0.041 & $\begin{array}{c}\text { not statistically } \\
\text { significant }\end{array}$ \\
\hline CP & 0.101 & 0.05 & 0.087 & $\begin{array}{c}\text { not statistically } \\
\text { significant }\end{array}$ \\
\hline FIS & 0.010 & not statistically significant & 0.125 & 0.01 \\
\hline FS & 0.002 & not statistically significant & 0.014 & $\begin{array}{c}\text { not statistically } \\
\text { significant }\end{array}$ \\
\hline FAI & 0.006 & not statistically significant & 0.003 & $\begin{array}{c}\text { not statistically } \\
\text { significant }\end{array}$ \\
\hline FDI & 0.036 & not statistically significant & 0.080 & $\begin{array}{c}\text { not statistically } \\
\text { significant }\end{array}$ \\
\hline RTT & 0.013 & not statistically significant & 0.0461 & $\begin{array}{c}\text { not statistically } \\
\text { significant }\end{array}$ \\
\hline
\end{tabular}

Note: $v$ is the number of degrees of freedom 
Thus, the analysis performed for specified periods showed the absence of connection or the presence of a weak connection between the performance criteria and the TCR (the values of the coefficient of determination are low, less than 0.3 ). That gives evidence of the weak impact of market criteria specific to the period of the TCR and, at the same time, evidence of the decisive role of structure and characteristics of the regional economy in a given region within the formation of the TCR, and that requires a set of influencing criteria for individual regions.

Out of 30 regions of the Central Federal District 4 regions were chosen for further investigation. The Yarolslavl region was naturally chosen as the home-region, along with its peer region Voronezh with a similar socio-economic development and allegedly similar high tax potential. Other two chosen regions of the same district, which are usually mentioned as being at the bottom in terms of tax capacity and socio-economic development, Ivanovo and Kostroma, were augmented for reference purposes. All four regions are located in the European part of Russia; they have similar natural conditions; comparable population; similar (in pairs) levels of tax potential; and socio-economic development in general (Yaroslavl and Voronezh regions are regarded as leaders in the CFD; while Ivanovo and Kostroma as outsiders). The statistical base of these regions was founded in 1997 (Table 5).

Table 5. The criteria and indicators of the rate of growth in the tax capacity of Yaroslavl, Voronezh, Ivanovo and Kostroma regions in 1997-2012, \%

\begin{tabular}{|c|c|c|c|c|c|c|c|c|c|}
\hline & TCR & GRP & FIS & PILSC & $\mathrm{CP}$ & FS & RTT & FIS & FAI \\
\hline \multicolumn{10}{|c|}{ Yaroslavl region } \\
\hline 1997 & 102.04 & 96.78 & & 104.40 & 54.20 & 97.62 & 91.34 & & \\
\hline 1998 & 50.27 & 66.56 & & 59.30 & 22.00 & 98.71 & 66.46 & & 73.93 \\
\hline 1999 & 124.93 & 120.90 & 701.62 & 119.60 & 202.26 & 102.65 & 117.27 & & 213.85 \\
\hline 2000 & 122.85 & 106.88 & 129.62 & 116.80 & 112.07 & 102.32 & 99.40 & 16.65 & 260.38 \\
\hline 2001 & 134.98 & 126.58 & 107.89 & 113.85 & 108.56 & 99.50 & 103.39 & 144.87 & 390.48 \\
\hline 2002 & 120.03 & 105.35 & 50.36 & 115.21 & 82.28 & 101.88 & 105.94 & 227.64 & 196.64 \\
\hline 2003 & 79.81 & 94.50 & 108.03 & 114.47 & 80.88 & 98.61 & 105.16 & 359.88 & 196.76 \\
\hline 2004 & 97.10 & 109.33 & 76.75 & 108.54 & 80.00 & 100.56 & 110.83 & 50.47 & 134.31 \\
\hline 2005 & 102.49 & 103.95 & 107.37 & 107.61 & 108.50 & 99.13 & 113.19 & 81.63 & 141.13 \\
\hline 2006 & 91.19 & 105.67 & 105.92 & 120.16 & 99.04 & 100.69 & 118.47 & 49.36 & 79.15 \\
\hline 2007 & 126.87 & 107.27 & 115.10 & 108.09 & 112.73 & 100.48 & 114.27 & 474.09 & 104.85 \\
\hline 2008 & 98.69 & 100.35 & -21.09 & 110.26 & 59.28 & 99.90 & 116.97 & 80.94 & 108.73 \\
\hline 2009 & 85.52 & 90.36 & 30.66 & 92.59 & 95.45 & 97.75 & 92.79 & 57.84 & 94.97 \\
\hline 2010 & 109.77 & 99.67 & -850.10 & 90.59 & 156.13 & 98.13 & 102.35 & 42.87 & 114.02 \\
\hline 2011 & 115.32 & 114.84 & 70.22 & 99.23 & 84.34 & 99.08 & 114.62 & 85.35 & 91.21 \\
\hline 2012 & 119.77 & 105.59 & 267.00 & 112.67 & 155.85 & 100.30 & 105.09 & 756.76 & 89.61 \\
\hline \multicolumn{10}{|c|}{ Voronezh region } \\
\hline 1997 & 105.27 & 102.88 & & 126.85 & & 97.92 & 110.27 & & 84.26 \\
\hline 1998 & 55.68 & 59.18 & & 68.01 & & 96.86 & 82.65 & & 63.81 \\
\hline 1999 & 114.07 & 118.76 & -5872.17 & 110.88 & 183.50 & 111.78 & 107.90 & 330.15 & 110.97 \\
\hline
\end{tabular}


Continue of Table 5

\begin{tabular}{|c|c|c|c|c|c|c|c|c|c|}
\hline & TCR & GRP & FIS & PILSC & $\mathrm{CP}$ & FS & RTT & FIS & FAI \\
\hline 2000 & 102.53 & 111.39 & 59.44 & 96.58 & 73.01 & 98.72 & 97.83 & 95.08 & 119.52 \\
\hline 2001 & 106.62 & 102.82 & 81.70 & 115.24 & 97.23 & 98.67 & 113.98 & 117.93 & 107.59 \\
\hline 2002 & 119.33 & 120.38 & -7.13 & 109.76 & 73.69 & 101.43 & 100.22 & 169.09 & 134.30 \\
\hline 2003 & 82.60 & 101.70 & 243.32 & 118.02 & 128.93 & 97.63 & 108.24 & 46.36 & 110.79 \\
\hline 2004 & 94.41 & 102.93 & -507.29 & 107.96 & 101.72 & 99.41 & 111.93 & 172.87 & 97.25 \\
\hline 2005 & 106.68 & 103.91 & 123.10 & 121.23 & 111.84 & 99.61 & 113.39 & 84.76 & 119.56 \\
\hline 2006 & 109.13 & 114.55 & 130.27 & 118.20 & 103.46 & 100.16 & 103.46 & 187.64 & 124.91 \\
\hline 2007 & 115.25 & 117.41 & 131.59 & 106.26 & 123.86 & 100.45 & 109.28 & 129.73 & 147.16 \\
\hline 2008 & 104.72 & 112.72 & 130.64 & 108.94 & 130.64 & 100.25 & 124.79 & 65.62 & 126.13 \\
\hline 2009 & 85.17 & 94.78 & 24.08 & 98.79 & 49.60 & 99.11 & 100.13 & 147.28 & 90.77 \\
\hline 2010 & 111.88 & 100.98 & 60.64 & 104.76 & 127.12 & 99.91 & 108.00 & 132.40 & 129.33 \\
\hline 2011 & 114.71 & 130.65 & 300.00 & 111.54 & 139.00 & 100.06 & 117.83 & 273.09 & 110.54 \\
\hline 2012 & 116.27 & 118.51 & 246.28 & 112.18 & 125.03 & 100.28 & 114.33 & 75.52 & 110.21 \\
\hline \multicolumn{10}{|c|}{ Ivanovo region } \\
\hline 1997 & 105.45 & 85.50 & & 109.95 & & 99.30 & 106.90 & & 93.07 \\
\hline 1998 & 53.06 & 63.00 & & 53.23 & & 93.50 & 56.34 & & 96.89 \\
\hline 1999 & 101.45 & 101.22 & -64.29 & 103.98 & 136.77 & 102.44 & 102.79 & 287.77 & 47.22 \\
\hline 2000 & 112.06 & 123.59 & 97.56 & 117.40 & 106.12 & 100.10 & 120.44 & 643.22 & 165.88 \\
\hline 2001 & 99.04 & 107.52 & 70.18 & 96.74 & 97.60 & 99.88 & 101.29 & 11.12 & 100.10 \\
\hline 2002 & 123.23 & 109.43 & -57.61 & 113.86 & 71.87 & 98.49 & 108.18 & 216.26 & 100.69 \\
\hline 2003 & 86.83 & 98.27 & 202.58 & 128.50 & 94.05 & 98.53 & 102.16 & 26.16 & 155.29 \\
\hline 2004 & 107.88 & 107.95 & -57.25 & 113.69 & 137.13 & 100.95 & 110.16 & 892.86 & 156.86 \\
\hline 2005 & 101.58 & 101.75 & 191.91 & 110.00 & 98.62 & 99.60 & 111.65 & 30.67 & 123.40 \\
\hline 2006 & 104.12 & 111.24 & 11.27 & 117.89 & 79.54 & 101.30 & 124.60 & 8968.61 & 109.50 \\
\hline 2007 & 104.63 & 118.20 & 1136.95 & 114.24 & 138.16 & 102.06 & 112.59 & 37.46 & 102.96 \\
\hline 2008 & 112.04 & 101.53 & 14.42 & 132.11 & 65.68 & 100.32 & 132.94 & 227.28 & 130.52 \\
\hline 2009 & 84.23 & 92.00 & -508.85 & 97.38 & 88.61 & 98.85 & 93.98 & 68.93 & 112.75 \\
\hline 2010 & 107.24 & 100.54 & 107.34 & 101.32 & 97.66 & 99.88 & 106.97 & 72.15 & 83.56 \\
\hline 2011 & 106.51 & 121.75 & 10.93 & 112.05 & 135.06 & 100.16 & 120.39 & 369.03 & 97.27 \\
\hline 2012 & 114.11 & 100.19 & -759.89 & 118.79 & 108.22 & 100.22 & 118.56 & 30.42 & 74.36 \\
\hline \multicolumn{10}{|c|}{ Kostroma region } \\
\hline 1997 & 135.96 & 108.88 & & 104.35 & & 97.57 & 98.54 & & 95.75 \\
\hline 1998 & 58.83 & 61.96 & & 58.68 & & 96.50 & 62.89 & & 71.06 \\
\hline 1999 & 92.47 & 119.32 & 1931.62 & 123.99 & 136.23 & 103.48 & 121.08 & 74.07 & 143.70 \\
\hline 2000 & 101.92 & 102.31 & 108.01 & 107.80 & 93.76 & 98.87 & 109.19 & 205.93 & 119.37 \\
\hline 2001 & 106.71 & 110.58 & 52.49 & 106.96 & 99.16 & 98.53 & 101.02 & 16.69 & 87.20 \\
\hline 2002 & 104.52 & 101.02 & -138.18 & 113.56 & 83.24 & 99.60 & 107.35 & 1206.90 & 110.75 \\
\hline 2003 & 101.39 & 94.87 & 23.11 & 89.05 & 70.67 & 99.63 & 106.55 & 308.37 & 82.91 \\
\hline 2004 & 92.18 & 112.72 & -189.96 & 111.51 & 124.64 & 100.12 & 113.38 & 549.52 & 189.10 \\
\hline
\end{tabular}


End of Table 5

\begin{tabular}{cccccccccc}
\hline & TCR & GRP & FIS & PILSC & CP & FS & RTT & FIS & FAI \\
\hline 2005 & 95.44 & 108.29 & 171.34 & 117.79 & 110.74 & 99.66 & 105.88 & 64.77 & 103.17 \\
\hline 2006 & 121.67 & 112.10 & 55.61 & 119.48 & 119.43 & 99.78 & 115.53 & 42.44 & 77.36 \\
\hline 2007 & 103.27 & 106.88 & 415.51 & 109.93 & 126.60 & 100.22 & 110.81 & 25.01 & 104.11 \\
\hline 2008 & 113.78 & 108.87 & 90.08 & 106.21 & 100.89 & 99.88 & 114.79 & 126.09 & 106.83 \\
\hline 2009 & 89.00 & 89.51 & 0.20 & 98.74 & 55.50 & 97.87 & 97.22 & 87.32 & 61.83 \\
\hline 2010 & 100.40 & 105.45 & 48842.80 & 108.18 & 142.83 & 101.36 & 109.88 & 47.46 & 120.13 \\
\hline 2011 & 104.40 & 114.26 & 94.11 & 103.20 & 97.17 & 97.98 & 110.85 & 231.79 & 95.24 \\
\hline 2012 & 102.97 & 109.85 & 210.27 & 99.20 & 162.24 & 98.57 & 102.15 & 106.31 & 129.42 \\
\hline
\end{tabular}

The results of correlation and regression analysis, the relationship between the performance criteria and the TCR for Yaroslavl, Voronezh, Ivanovo and Kostroma regions are presented in Table 6.

Large coefficients of determination suggest existence of association between criteria and results, and that structure of the regional economy determines the structure and formation of the TCR (contrary to what was observed in the analysis performed for specified periods for all regions of the Central Federal District). Moreover, the coefficients of determination, which reveal the level of association between criteria and results, appeared to be different in regions, which proves that such associations depend on particularities of economy of every region.

It is notable that instability of net corporate profit among the regions has led to the absence of the relationship with this variable (see Table 6). In addition, such extreme points as in 1997-1999 and in 2009-2010, which were related to crises occurred in the economy of the Russian Federation, cause the reference-point effect, and produce negative effect on quality of the regression model. Nevertheless, it was decided not to exclude such values from the model for the purpose of using it in the future, when crises can occur as well.

For the purpose of choosing the most important criteria, which will be used in the further research presented below in the paper, the results of correlation-regression analysis presented in Table 6, were used. As the major part of taxes is collected from the following taxes: VAT; excise; corporate income tax; personal income tax; and property taxes, the criteria should be chosen to be related to the outlined taxes to reflect dynamics of tax income from the named taxes.

The highest level of dependence is noted between the TCP and GRP, and between the TCP and RTT. Retail trade turnover and the GRP are forming the major part of tax base related to the indirect taxes, therefore one criterion should be included in the model. Observations that dependence between the TCP and GRP is higher, and that the GRP is a general variable, which reflects the state of the regional economy, have determined the choice in favor of this criterion instead of retail trade turnover.

A high level of dependence could also be observed between the TCP and PILSC, which could be explained by the fact that the PILSC practically forms the total tax base of personal income, and personal income is forming a large part of the TCP. The FAI should also be 
Table 6. The results of correlation and regression analysis, the relationship between the performance criteria and the tax capacity of the region in 1997-2012 (Steam regression)

\begin{tabular}{|c|c|c|c|c|c|c|c|c|c|c|c|c|}
\hline \multirow{3}{*}{ 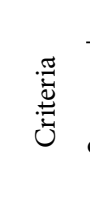 } & \multicolumn{3}{|c|}{ Yaroslavl region } & \multicolumn{3}{|c|}{ Voronezh region } & \multicolumn{3}{|c|}{ Invanovo region } & \multicolumn{3}{|c|}{ Kostroma region } \\
\hline & \multirow{2}{*}{$\begin{array}{l}\mathrm{R}^{2} \text { the } \\
\text { line } \\
\text { connec- } \\
\text { tion }\end{array}$} & \multicolumn{2}{|c|}{$\begin{array}{l}\text { The best } \\
\text { connection }\end{array}$} & \multirow{2}{*}{$\begin{array}{l}\mathrm{R}^{2} \text { the } \\
\text { line } \\
\text { connec- } \\
\text { tion }\end{array}$} & \multicolumn{2}{|c|}{$\begin{array}{l}\text { The best } \\
\text { connection }\end{array}$} & \multirow{2}{*}{$\begin{array}{l}\mathrm{R}^{2} \text { the } \\
\text { line } \\
\text { connec- } \\
\text { tion }\end{array}$} & \multicolumn{2}{|c|}{$\begin{array}{l}\text { The best } \\
\text { connection }\end{array}$} & \multirow{2}{*}{$\begin{array}{l}\mathrm{R}^{2} \text { the } \\
\text { line } \\
\text { connec- } \\
\text { tion }\end{array}$} & \multicolumn{2}{|c|}{$\begin{array}{l}\text { The best } \\
\text { connection }\end{array}$} \\
\hline & & Type & $\mathrm{R}^{2}$ & & Type & $\mathrm{R}^{2}$ & & Type & $\mathrm{R}^{2}$ & & Type & $\mathrm{R}^{2}$ \\
\hline GRP & 0.775 & grade & 0.83 & 0.796 & grade & 0.85 & 0.545 & grade & 0.66 & 0.444 & $\begin{array}{l}\text { polyno- } \\
\text { mial } 2 \text { gr. }\end{array}$ & 0.70 \\
\hline PILSC & 0.426 & $\begin{array}{l}\text { polyno- } \\
\text { mial } 2 \text { gr. }\end{array}$ & 0.59 & 0.429 & $\begin{array}{l}\text { polyno- } \\
\text { mial } 2 \text { gr. }\end{array}$ & 0.65 & 0.581 & grade & 0.73 & 0.316 & $\begin{array}{l}\text { polyno- } \\
\text { mial } 2 \text { gr. }\end{array}$ & 0.61 \\
\hline $\mathrm{CP}$ & 0.394 & grade & 0.598 & & & & & & & & & \\
\hline FS & 0.246 & $\begin{array}{l}\text { polyno- } \\
\text { mial } 2 \text { gr. }\end{array}$ & 0.28 & 0.207 & $\begin{array}{l}\text { polyno- } \\
\text { mial } 2 \text { gr. }\end{array}$ & 0.24 & 0.508 & $\begin{array}{l}\text { polyno- } \\
\text { mial } 2 \text { gr. }\end{array}$ & 0.79 & & & \\
\hline FAI & 0.266 & $\begin{array}{l}\text { polyno- } \\
\text { mial } 2 \text { gr. }\end{array}$ & 0.39 & 0.552 & grade & 0.63 & & & & & & \\
\hline FDI & & & & & & & & & & & & \\
\hline RTT & 0.330 & $\begin{array}{l}\text { polyno- } \\
\text { mial } 2 \text { gr. }\end{array}$ & 0.60 & 0.367 & $\begin{array}{l}\text { polyno- } \\
\text { mial } 2 \text { gr. }\end{array}$ & 0.53 & 0.736 & grade & 0.84 & 0.312 & $\begin{array}{l}\text { polyno- } \\
\text { mial } 2 \text { gr. }\end{array}$ & 0.77 \\
\hline
\end{tabular}

included to the set of criteria as the criterion in spite of the absence of its clear statistical dependence, as it is forming a large part of tax base of corporate property.

Among the criteria reflecting corporate profits only the CP criterion showed some statistical dependence, only for Yaroslavl district. We chose not to omit this criterion for performing the analysis.

To summarize, the following criteria were chosen: GRP; PILSC; PILSC; FAI. They form the tax base stemming from the VAT, excises, personal income, corporate profits, and corporate property. Regression analysis confirmed influence of these criteria on the TCP.

\section{Multiple criteria (MCDM) approach to the evaluation of the tax capacity of regions}

As in the realm of economics decisions are deemed to be made both on psychological grounds and rationality (Morselli 2015), expert evaluation helps to comprise both approaches. MCDM methods proved to be efficient in the realm of economics including finance (Brauers et al. 2014, 2012; Podviezko 2012; Podvezko, Podviezko 2010). Consequently, such methods along with regression analysis were chosen by the authors for evaluation of the TPR.

The basis of quantitative multiple criteria MCDM (Multiple Criteria Decision Making) techniques constitute two the matrix of decisions $\mathbf{R}=\left\|r_{i j}\right\|$, where values or criteria describing the purpose of the study are placed, and the vector $\Omega=\left(\omega_{i}\right)$ weights of these criteria, where $i=1,2, \ldots, m ; j=1,2, \ldots, n ; m$ - number of criteria, $n$-number of the compared options (regions). The major result of using MCDM techniques is finding out, which of the compared variants $A_{1}, A_{2, \ldots}, A_{n}$ (regions) is the best according to the set of values 
$r_{i j}$ of all criteria $R_{1}, R_{2}, \ldots, R_{m}$. In other words, to rank options in the order of importance (Tamosaitiene, Kaplinski 2013).

The idea of quantitative evaluation using MCDM methods is to join normalized values of criteria, which consequently are made dimensionless, and their weights into one cumulative criterion of evaluation. The simplest is the method of a simple additive weighting SAW (Simple Additive Weighting), evaluation criterion $S_{j}$ is calculated by the formula (Hwang, Yoon 1981):

$$
S_{j}=\sum_{i=1}^{m} \omega_{i} \tilde{r}_{i j},
$$

where $\omega_{i}$ is the weight of $i$-th criterion; $\tilde{r}_{i j}$ - normalized (dimensionless) value of the $i$-th criterion for the $j$-th option. One of normalization possibility, which we use in this paper, is:

$$
\tilde{r}_{i j}=\frac{r_{i j}}{\sum_{j=1}^{m} r_{i j}} .
$$

In order to increase reliability of results, we use another MCDM method - TOPSIS (Technique for Order Preference by Similarity to an Ideal Solution) for multiple-criteria evaluation. This method is one of the most popular; the most commonly used and theoretically grounded multiple-criteria methods. The idea of the method is that among the compared options an object that has the shortest distance from the best option (on the set of all criteria) and the one having the largest distance from the worst case scenario will be recognized as the best alternative (Hwang, Yoon, 1981; Ginevicius, Podviezko 2013; Podviezko, Podvezko 2014).

TOPSIS method uses vector data normalization:

$$
\tilde{r}_{i j}=\frac{r_{i j}}{\sqrt{\sum_{j=1}^{n} r_{i j}^{2}}},(i=1,2, . ., m ; j=1,2, \ldots, n),
$$

where $r_{i j}$ and $\tilde{r}_{i j}$ respectively, the value and the normalized value $i$-th criterion for the $j$-th alternative.

In the TOPSIS method first the best solution is constructed:

$$
V^{*}=\left\{V_{1}^{*}, V_{2}^{*}, \ldots, V_{m}^{*}\right\}=\left\{\left(\max _{j} \omega_{i} r_{i j} / i \in I_{1}\right),\left(\min _{j} \omega_{i} \tilde{r}_{i j} / i \in I_{2}\right)\right\},
$$

and the worst one is found,

$$
V^{-}=\left\{V_{1}^{-}, V_{2}^{-}, \ldots, V_{m}^{-}\right\}=\left\{\left(\min _{j} \omega_{i} r_{i j} / i \in I_{1}\right),\left(\max _{j} \omega_{i} \tilde{r}_{i j} / i \in I_{2}\right)\right\},
$$

where $I_{1}$ - the index set of maximized criteria, $I_{2}$ - the set of indexes of minimizing criteria, $\omega_{i}$ the weight of the $i$-th criterion.

Both distances $D_{j}^{*}$ of each alternative to the best solution, and the distance $D_{j}^{-}$to the worst solution are calculated:

$$
D_{j}^{*}=\sqrt{\sum_{i=1}^{m}\left(\omega_{i} \tilde{r}_{i j}-V_{i}^{*}\right)^{2}},
$$




$$
D_{j}^{-}=\sqrt{\sum_{i=1}^{m}\left(\omega_{i} \tilde{r}_{i j}-V_{i}^{-}\right)^{2}}
$$

The cumulative criterion $C_{j}^{*}$ of the method TOPSIS is calculated by the formula:

$$
C_{j}^{*}=\frac{D_{j}^{-}}{D_{j}^{*}+D_{j}^{-}}(j=1,2, \ldots, n),\left(0 \leq C_{j}^{*} \leq 1\right) .
$$

The best alternative corresponds to the largest value of the criterion $C_{j}^{*}$; alternatives are ranked in the descending order, in correspondence to the values of the cumulative criteria.

In practice, from weights elicited from qualified experts the weights suitable for the calculation can be created. Nevertheless, concordance of the opinions must be a priori tested using the theory of rank correlation by Kendall. The coefficient of concordance $W$ allows to gauge the degree of consistency (Kendall 1955). Ranking is a common procedure, when the most important criterion is assigned rank equal to one, the second most important is assigned rank 2, and so on, the last which is the least important criterion is assigned a rank $m$ (where $m$ - a number of criteria).

Consequently, the table-matrix of ranks $E=\left\|e_{i j}\right\|(i=1, \ldots, m ; j=1, \ldots, r)$ is created, where $m$ is an amount of compared criteria and $r$ is the number of experts.

The coefficient of concordance $W$ is calculated by the formula (Kendall 1955):

$$
W=\frac{12 S}{r^{2} m\left(m^{2}-1\right)} \text {. }
$$

In the formula (10) the sum of squared deviations $S$ i-rank-sum $e_{i}=\sum_{j=1}^{r} e_{i j} i$-th criterion for all experts of the total medium $\bar{e}=\frac{\sum_{i=1}^{m} e_{i}}{m}=\frac{\sum_{i=1}^{m} \sum_{j=1}^{r} e_{i j}}{m}$ is calculated by the formula:

$$
S=\sum_{i=1}^{m}\left(e_{i}-\bar{e}\right)^{2}
$$

The degree of coherence of expert evaluations is not indicated by the coefficient of concordance $W$, but by test statistics $\chi^{2}$ whose values are calculated by the formula:

$$
\chi^{2}=W r(m-1)=\frac{12 S}{r m(m+1)} .
$$

It was proved (Kendall 1955), that if the value $\chi^{2}$ exceeds the critical value of criteria $\chi_{k r}^{2}$, taken from the $\chi^{2}$ distribution table, for the number of degrees of freedom $v=m-1$, and the chosen significance level $\alpha$, then the null hypothesis about non-concordance of expert opinions can be rejected and therefore the alternative hypothesis is accepted.

At the first phase weights of importance of 10 criteria were ranked in accordance with opinions of 11 experts. The qualitative criteria, characterizing the level of development of the TCR (Table 5), have been added to statistical criteria from Table 5. Estimated value of 
the concordance coefficient $W=0.326$, and the corresponding value criterion $\chi^{2}=32.316$ has exceeded the critical value $\chi_{k r}^{2}=16.919$, taken from the table of $\chi^{2}$ distribution, for the number of degrees of freedom $v=9$ and the chosen significance level $\alpha=0.05$. Consequently, the statistical hypothesis about the consistency of expert opinions was adopted.

\section{Estimates of weights of criteria, which determine the tax capacity of regions}

In decision-making problems the so-called subjective weights of criteria are often used. They are calculated from elicited opinions of qualified experts in theory and practice in the realm, where the investigation takes place. A few methods of estimating weights were created (Saaty 1980; Hwang, Yoon 1981; Podvezko, Sivilevicius 2013; Zavadskas et al. 2012; Kersuliene et al. 2010). The general idea of such a subjective estimation of weights is that the weight of the most important criterion should have the largest value. Magnitudes of weights correspond to the level of importance of criteria. Usually, the values of weights are normalized so that their sum equals the unity:

$$
\sum_{i=1}^{m} \omega_{i}=1 .
$$

The method of direct estimation of weights when the sum of estimated weights for all the four criteria by each expert make up $100 \%$ was used in the paper.

The so-called objective weights of criteria, which are elicited from the structure of data given in the decision-matrix are estimated based on the level of dominance of criteria among themselves (Hwang, Yoon 1981; Cheng 2010; Hajiagha et al. 2012). Such objective weights of criteria are used in decision-making problems as well, and are estimated in this paper by using the multivariate regression model.

Such objective weights are rarely used in decision-making problems. Methods, which comprise both subjective and objective weights, are also available (Hwang, Yoon 1981; Ma et al. 1999).

Cumulative weights are calculated by the formula:

$$
\omega_{i}=\frac{q_{i} W_{i}}{\sum_{i=1}^{m} q_{i} W_{i}},
$$

where $q_{i}$ is a subjective weight, $W_{i}$ - objective weight $\omega_{i}$ - cumulative weight.

Such cumulative weights comprise both opinions of qualified experts and data structure, namely the degree of mutual dominance of criteria at the time of evaluation.

Four criteria, selected by the results of regression analysis and expert opinions, were used in the analysis. Consequently, experts were asked to estimate their weights of relative importance in terms of their impact on the TCR. Summary of opinions of experts is presented in Table 7. 
Table 7. Summary of opinions of experts on the degree of influence of criteria on the TCR

\begin{tabular}{cccccccccccc}
\hline \multirow{2}{*}{ Ranks of criteria } & \multicolumn{8}{c}{ Expert evaluation (E is an expert) } \\
& E1 & E2 & E3 & E4 & E5 & E6 & E7 & E8 & E9 & E10 & E11 \\
\hline GRP & 3 & 1 & 3 & 1 & 1 & 4 & 2 & 3 & 4 & 1 & 3 \\
\hline CP & 1 & 2 & 2 & 3 & 2 & 2 & 1 & 2 & 2 & 2 & 1 \\
\hline PILSC & 2 & 3 & 1 & 2 & 3 & 3 & 3 & 1 & 3 & 3 & 2 \\
\hline FAI & 4 & 4 & 4 & 4 & 4 & 1 & 4 & 4 & 1 & 4 & 4 \\
\hline GRP & Opinions & on & weights & of criteria, & $\%$ & & & & & \\
\hline CP & 15 & 35 & 20 & 35 & 35 & 15 & 31 & 25 & 15 & 40 & 20 \\
\hline PILSC & 40 & 27 & 25 & 25 & 30 & 30 & 35 & 30 & 25 & 25 & 40 \\
\hline FAI & 35 & 25 & 35 & 25 & 25 & 20 & 25 & 35 & 20 & 20 & 25 \\
\hline Total & 10 & 13 & 20 & 15 & 10 & 35 & 9 & 10 & 40 & 15 & 15 \\
\hline & 100 & 100 & 100 & 100 & 100 & 100 & 100 & 100 & 100 & 100 & 100 \\
\hline
\end{tabular}

Expert estimates are denoted as $e_{i k}$. Weights are found as follows:

$$
q_{i}=\frac{\sum_{k=1}^{r} e_{i k}}{100 \sum_{i=1}^{m} \sum_{k=1}^{r} e_{i k}},\left(\sum_{i=1}^{m} q_{i}=1\right) .
$$

In Table 8 values of subjective and objective weights are provided, as well as cumulative weights calculated by formula (14).

Table 8. Weights of TCR criteria

\begin{tabular}{cccc}
\hline Criterion & Subjective weight, $q_{i}$ & Objective weight, $W_{i}$ & Generalized weight, $\omega_{i}$ \\
\hline GRP & 0.260 & 0.340 & 0.351 \\
\hline PILSC & 0.302 & 0.233 & 0.280 \\
\hline CP & 0.264 & 0.209 & 0.219 \\
\hline FAI & 0.174 & 0.217 & 0.150 \\
\hline
\end{tabular}

\section{Comparative multiple criteria evaluation of perspective regions of the Russian Federation}

Using multiple criteria decision-making (MCDM) methods SAW and TOPSIS, the tax capacity of four regions of Russia: Yaroslavl; Voronezh; Ivanovo; and Kostroma for the period 2000-2012 was evaluated. The period was curtailed as for 1997-1999 statistical data for some criteria was not available (see Table 5). Cumulative weights calculated by formula (14) based both on expert opinions, and correlation and regression analysis were used. Calculation results are presented in Table 9.

Results of evaluation provided in Table 9 revealed a very good correspondence between results obtained using the methods SAW and TOPSIS. Minor discrepancies among rankings of evaluations could be noticed only in 2004 and 2010. The differences were induced by small deviations between the cumulative criteria (deviation values for Yaroslavl and Voronezh regions made up 0.004 and 0.02). Moreover, some discrepancy allowance should 
be reserved because of subjectivity in estimations of weights of criteria. Additional information about the TCR of the chosen regions was obtained using the stochastic approach. Correlation and regression prediction analysis of the TCR was performed using the available empirical data. The model is described by the following regression equation (16):

$$
\text { TCR }_{i}=-84.778+14.298 \text { GRP }_{i}+3.575 \text { PILSC }_{i}+0.009 C P_{i}+0.029 \text { FAI }_{i} .
$$

Table 9. Results of multiple-criteria evaluation of gain of the TCR in four regions of Russia in 2000-2012

\begin{tabular}{|c|c|c|c|c|c|c|c|c|c|}
\hline \multirow[t]{2}{*}{ Year } & \multirow{2}{*}{$\begin{array}{c}\text { Districts } \\
\text { TOPSIS }\end{array}$} & \multicolumn{2}{|c|}{ Yaroslavl } & \multicolumn{2}{|c|}{ Voronezh } & \multicolumn{2}{|c|}{ Ivanovo } & \multicolumn{2}{|c|}{ Kostroma } \\
\hline & & 0.5408 & 3 & 0.5720 & 2 & 0.2740 & 4 & 0.6804 & 1 \\
\hline \multirow[t]{3}{*}{2012} & SAW & 0.2518 & 3 & 0.2574 & 2 & 0.2267 & 4 & 0.2641 & 1 \\
\hline & Rank & 3 & & 2 & & 4 & & 1 & \\
\hline & TOPSIS & 0.0137 & 4 & 0.9891 & 1 & 0.7556 & 2 & 0.2164 & 3 \\
\hline \multirow[t]{3}{*}{2011} & SAW & 0.2242 & 4 & 0.2774 & 1 & 0.2643 & 2 & 0.2341 & 3 \\
\hline & Rank & 4 & & 1 & & 2 & & 3 & \\
\hline & TOPSIS & 0.6505 & 2 & 0.6300 & 3 & 0.2028 & 4 & 0.8043 & 1 \\
\hline \multirow[t]{3}{*}{2010} & SAW & 0.2522 & 3 & 0.2562 & 2 & 0.2257 & 4 & 0.2659 & 1 \\
\hline & Rank & $2-3$ & & $2-3$ & & 4 & & 1 & \\
\hline & TOPSIS & 0.7916 & 2 & 0.2817 & 3 & 0.8606 & 1 & 0.1460 & 4 \\
\hline \multirow[t]{3}{*}{2009} & SAW & 0.2653 & 2 & 0.2375 & 3 & 0.2725 & 1 & 0.2248 & 4 \\
\hline & Rank & 2 & & 3 & & 1 & & 4 & \\
\hline & TOPSIS & 0.0528 & 4 & 0.7541 & 1 & 0.3136 & 3 & 0.5049 & 2 \\
\hline \multirow[t]{3}{*}{2008} & SAW & 0.2216 & 4 & 0.2805 & 1 & 0.2468 & 3 & 0.2512 & 2 \\
\hline & lace & 4 & & 1 & & 3 & & 2 & \\
\hline & TOPSIS & 0.0635 & 4 & 0.6800 & 1 & 0.5138 & 2 & 0.2715 & 3 \\
\hline \multirow[t]{3}{*}{2007} & SAW & 0.2362 & 4 & 0.2617 & 1 & 0.2592 & 2 & 0.2429 & 3 \\
\hline & Rank & 4 & & 1 & & 2 & & 3 & \\
\hline & TOPSIS & 0.3302 & 4 & 0.7266 & 1 & 0.3634 & 3 & 0.5523 & 2 \\
\hline \multirow[t]{3}{*}{2006} & SAW & 0.2387 & 4 & 0.2646 & 1 & 0.2428 & 3 & 0.2539 & 2 \\
\hline & Rank & 4 & & 1 & & 3 & & 2 & \\
\hline & TOPSIS & 0.5803 & 2 & 0.6129 & 1 & 0.3402 & 4 & 0.4669 & 3 \\
\hline \multirow[t]{3}{*}{2005} & SAW & 0.2520 & 2 & 0.2554 & 1 & 0.2412 & 4 & 0.2514 & 3 \\
\hline & Rank & 2 & & 1 & & 4 & & 3 & \\
\hline & TOPSIS & 0.2554 & 4 & 0.2587 & 3 & 0.7800 & 2 & 0.8408 & 1 \\
\hline \multirow[t]{3}{*}{2004} & SAW & 0.2318 & 3 & 0.2274 & 4 & 0.2681 & 2 & 0.2727 & 1 \\
\hline & Rank & $3-4$ & & $3-4$ & & 2 & & 1 & \\
\hline & TOPSIS & 0.5379 & 3 & 0.6243 & 1 & 0.5962 & 2 & 0.0065 & 4 \\
\hline \multirow[t]{3}{*}{2003} & SAW & 0.2578 & 3 & 0.2710 & 1 & 0.2662 & 2 & 0.2051 & 4 \\
\hline & Rank & 3 & & 1 & & 2 & & 4 & \\
\hline & TOPSIS & 0.6910 & 1 & 0.4966 & 2 & 0.2036 & 4 & 0.2401 & 3 \\
\hline \multirow[t]{2}{*}{2002} & SAW & 0.2684 & 1 & 0.2538 & 2 & 0.2370 & 4 & 0.2408 & 3 \\
\hline & Rank & 1 & & 2 & & 4 & & 3 & \\
\hline
\end{tabular}


End of Table 9

\begin{tabular}{llrlrrrrrr}
\hline Year & Districts & Yaroslavl & Voronezh & \multicolumn{2}{c}{ Ivanovo } & \multicolumn{2}{c}{ Kostroma } \\
\hline \multirow{2}{*}{2001} & TOPSIS & 0.9848 & 1 & 0.1888 & 2 & 0.0731 & 4 & 0.1402 & 3 \\
\cline { 2 - 12 } & SAW & 0.3115 & 1 & 0.2316 & 2 & 0.2219 & 4 & 0.2290 & 3 \\
\cline { 2 - 11 } & Rank & 1 & & 2 & & 4 & & 3 & \\
\hline \multirow{2}{*}{2000} & TOPSIS & 0.7500 & 1 & 0.1498 & 4 & 0.5953 & 2 & 0.2729 & 3 \\
\cline { 2 - 11 } & SAW & 0.2815 & 1 & 0.2182 & 4 & 0.2704 & 2 & 0.2299 & 3 \\
\cline { 2 - 10 } & Rank & 1 & & 4 & & 2 & & 3 & \\
\hline
\end{tabular}

The coefficient of determination R2 appeared to be $69.6 \%$. F-Fisher test at a significance level $(\alpha)$ of $1 \%$ was performed. Consequently, the multiple regression equation is found to be statistically significant. The average error of approximation $(\overline{\mathrm{A}})$ was $8.25 \%$. These figures together indicate that the model is acceptable and can be used for the analytical purposes.

In this model the dependent variable reflects the growth rate, which depend on chosen variables. Table 10 shows the ranks resulting from evaluation of the TCR of the regions on the basis of correlation-regression analysis model.

Comparison of the ranks obtained using the stochastic approach (Table 10) and the ones obtained using MCDM methods (Table 9) for the four chosen regions showed rather good correspondence. There is a full correspondence between obtained ranks for the following years: 2003, 2004, 2006-2008, 2010, and 2011. Some differences were found for 2000-2002, 2005,2009 , and 2012. A few possible causes of the discrepancies could be named. Values of criteria, which determine growth of the TCR, are often close among the regions. Therefore, even small differences of such values result in differences in ranks. Weights are different, ones obtained by expert evaluation and by the correlation-regression analysis. Also, the presence of unexplained variation makes unexpected effects on the result.

Table 10. The comparative evaluation of growth of tax capacity in four regions of Russia in 20002012 based on regression analysis

\begin{tabular}{lcccc}
\hline Year & Yaroslavl & Voronezh & Ivanovo & Kostroma \\
\hline 2012 & 3 & 1 & 4 & 2 \\
\hline 2011 & 4 & 1 & 2 & 3 \\
\hline 2010 & 3 & 2 & 4 & 1 \\
\hline 2009 & 3 & $1-2$ & $1-2$ & 4 \\
\hline 2008 & 4 & 1 & 3 & 2 \\
\hline 2007 & 4 & $1-2$ & $1-2$ & 3 \\
\hline 2006 & 4 & 1 & 3 & 2 \\
\hline 2005 & $2-3$ & $2-3$ & 4 & 1 \\
\hline 2004 & 3 & 4 & 2 & 1 \\
\hline 2003 & 3 & 1 & 2 & 4 \\
\hline 2002 & $2-3$ & 1 & $2-3$ & 4 \\
\hline 2001 & 1 & 4 & 3 & 2 \\
\hline 2000 & 2 & 3 & 1 & 4 \\
\hline
\end{tabular}


In general, we can conclude that using both MCDM and regression techniques to explore the options for evaluating and predicting the TCR is promising because of extremely negligible discrepancies between results obtained using such different methods as MCDM methods and regression analysis. The discrepancies could be explained by the effects of normalization of data. As in the sub-set such criteria that relate to the rate of growth values differ insignificantly, the MCDM methods become more sensitive to the data. It could be assumed that in the case if only criteria, which relate to the TCR were kept, MCDM methods would reveal the absolute degree of stability in terms of results, as differences between values of such criteria are more substantial, than values of criteria that relate to the rate of growth of the TCR. Nevertheless, absolute matching of ranks obtained by different evaluation methods is rarely found in the literature.

\section{Conclusions}

The study identified criteria that influence tax capacity of regions of the Russian Federation: gross regional product, personal income excluding social security contributions, corporate profit, investment in fixed assets. The set of the criteria was elicited from the structure of the TCR, and tax bases of component taxes. In the paper choice of criteria was made empirically using regression analysis. The results obtained by the empirical research were comprised with the results of expert evaluations, which were ultimately summarized using multiple criteria methods. The novel part of the paper is applying evaluation of the TCR of different regions by using simultaneously two different approaches: MCDA and regression analysis. The paper provides some insight on particularities of evaluation of tax capacity of the regions of the Russian Federation.

Comparative evaluation of the TCR of chosen regions of the Central Federal District of Russia for the period 2000-2012 using two MCDM methods showed the existence of minor differences between ranks caused by similarity of values of the criteria, which relate to the rate of growth of the TCR. The use of criteria that relate only to the current state of the TCR should have led to almost complete coincidence of ranks. It is important to note, that most periods are characterized by absolute similarity of ranks in the regions by the TCR obtained by different methods, which proves the suitability of multiple criteria assessment methods, and regression analysis. Such a combination of two different methods is a novel approach.

Tax authorities, which administer collection of taxes, should be interested in the research as contrary to the available information it reveals a different view on tax capacity of the regions. At times the regions, which are regarded to be leaders (Yaroslavl and Voronezh) are found at the bottom, and contrary the allegedly lagging regions (Ivanovo and Kostroma) are attaining good positions. Knowing relative positions of the regions allows finding causes of the lagging or prominent positions in terms of values of criteria, which describe the TPR. 


\section{References}

Barro, S. M. 1986. State fiscal capacity measures: a theoretical critique, in H. C. Reeves (Ed.). Measuring fiscal capacity. (pp. 50-86). Boston: Lincoln Institute of Land Policy.

Bird, R. M.; Martinez-Vazquez, J. 2008. Tax effort in developing countries and high income countries: the impact of corruption, voice and accountability. Atlanta, Georgia: Georgia State University.

Bird, R. M.; Martinez-Vazquez, J.; Torgler, B. 2004. Societal institutions and tax effort in developing countries. Toronto: University of Toronto.

Bivainis, J.; Skackauskiene, I. 2008. Mokesčių sistema Lietuvoje: vertinimas Gill metodu, Viešasis Administravimas 1(17): 43-61 (in Lithuanian).

Brauers, W.; Ginevicius, R.; Podviezko, A. 2014. Development of a methodology of evaluation of financial stability of commercial banks, Panoeconomicus 61(3): 349-367.

http://dx.doi.org/10.2298/PAN1403349B

Brauers, W. K.; Ginevicius, R.; Podviezko, A. 2012. Evaluation of performance of Lithuanian commercial banks by multi-objective optimization, in R. Ginevicius, A. V. Rutkauskas, J. Stankeviciene (Eds.). The 7th International Scientific Conference Business and Management'2012. Selected papers. (pp. 1042-1049). Vilnius, Lithuania: Technika.

Burman, L. E.; Phaup, M. 2011. Tax expenditures, the size and efficiency of government, and implications of budget reform, in Tax Policy and the Economy, Volume 26. Chicago: University of Chicago Press.

Bushinsky, T.V. 2009. Regional tax policy and characteristics its implementation (in the Tula region). Moscow: VZFEI.

Cheng, Q. 2010. Structure entropy weight method to confirm the weight of evaluating index, Systems Engineering-Theory \& Practice 30(7): 1225-1228.

Eltony, M. N. 2002. The determinants of tax effort in Arab Countries, ERF Working Paper 200229: 1-11.

Gilardi, F.; Wasserfallen, F. 2014. How socialization attenuates tax competition, British Journal of Political Science 2014: 1-21.

Ginevicius, R.; Podviezko, A. 2013. The evaluation of financial stability and soundness of Lithuanian banks, Ekonomska Istrazivanja-Economic Research 26(2): 191-208.

http://dx.doi.org/10.1080/1331677X.2013.11517616

Hajiagha, S. H. R.; Hashemi, S. S.; Zavadskas, E. K.; Akrami, H. 2012. Extensions of LINMAP model for multi criteria decision making with grey numbers, Technological and Economic Development of Economy 18(4): 636-650. http://dx.doi.org/10.3846/20294913.2012.740518

Hanafeev, F. F. 2008. Methodology and analytical support for the management of tax potential of the region. Yoshkar-Ola, Russia: Volga State University of Technology.

Hwang, C. L.; Yoon, K. 1981. Multiple attribute decision making: methods and applications. Berlin: Springer-Verlag. http://dx.doi.org/10.1007/978-3-642-48318-9

Karataev, A. S. 2010. Criteria affecting the tax capacity of the largest taxpayer, Siberian Financial School 1(78): 42-47.

Kendall, M. 1955. Rank correlation methods. New York: Hafner Publishing House.

Kersuliene, V.; Zavadskas, E. K.; Turskis, Z. 2010. Selection of rational dispute resolution method by applying new step-wise weight assessment ratio analysis (SWARA), Journal of Business Economics and Management 11(2): 243-258. http://dx.doi.org/10.3846/jbem.2010.12

Kolesnikova, S. A. 2004. Tax relations in the economic system of society. Voronezh, Russia: Voronezh State University.

Krasnitsky, V. A. 2009. Tax policy in a market economy in the Russian Federation. Moscow: Finance Academy. 
Kuznetsova, L. N. 2007. Formation and development priorities of the tax potential of the subject of the Russian Federation. Saratov, Russia: Yuri Gagarin State Technical University of Saratov.

Le, T. M.; Moreno-Dodson, B.; Bayraktar, N. 2012. Tax capacity and tax effort: extended cross-country analysis from 1994 to 2009, Policy Research Working Paper No. WPS 6252, The World Bank.

Lotz, J. R.; Morss, E. 1970. A theory of tax level determinants for developing countries, Economic Development and Cultural Change 18: 328-341. http://dx.doi.org/10.1086/450436

Ma, J.; Fan, Z.-P.; Huang, L.-H. 1999. A subjective and objective integrated approach to determine attribute weights, European Journal of Operational Research 112(2): 397-404. http://dx.doi.org/10.1016/S0377-2217(98)00141-6

Matrusov, N.D. 1995. Regional forecasting and regional development of Russia. Moscow: Nauka.

Mironova, O. A.; Hanafeev, F. F. 2013. Tax administration: a textbook for university students studying the profiles direction "Economics" and "Taxes and taxation", "Economic Security". Yoshkar-Ola, Russia: String.

Morselli A. 2015. The decision-making process between convention and cognition, Economics and Sociology 8(1): 205-221. http://dx.doi.org/10.14254/2071-789X.2015/8-1/16

Naik, D. S. 2013. Goods and services tax in India: some issues, Golden Research Thoughts III(IV): 1-7.

Nasulea C. 2014. The effects of fiscal policy instability on wind energy resource development in Romania, Economics and Sociology 7(3): 51-59. http://dx.doi.org/10.14254/2071-789X.2014/7-3/4

OAO Sberbank. 2014. Rossiya: neformal'naya zanyatost' kak novyj fenomen [online], [cited 15 February 2016]. 10 p. Available from Internet: http//sberbank.ru/common/img/uploaded/analytics/2014/ neformaltrudf.pdf (in Russian)

Ong Lynette, H. 2011. Fiscal federalism and soft budget constraints: the case of China, International Political Science Review 33(4): 454-474.

Osipov, M.A. 2008. Tax stimulation of formation and realization of the regional economy investment potential. Moscow: Ekonomika.

Panskov, V. G. 2013. Tax risks and possible ways to minimize, Taxes and taxation 4: 74-80.

Parfenova, L. B.; Pugachev, A. A. 2013. Theoretical approaches to the definition of tax potential of region, Vestnik of Tver state university. Series: economy and management 19: 43-59.

Parfenova, L. B.; Pugachev, A. A.; Turina, T. E. 2013. Tax potential of the region: the nature, methods of assessment and development. Yaroslavl, Russia: Indigo.

Podvezko, V.; Podviezko, A. 2010. Use and choice of preference functions for evaluation of characteristics of socio-economical processes, in R. Ginevicius, A. V. Rutkauskas, R. Pocs (Eds.). The 6th International Scientific Conference Business and Management'2010. Selected papers. (pp. 1066-1071). Vilnius, Lithuania: Technika.

Podvezko, V.; Sivilevicius, H. 2013. The use of AHP and rank correlation methods for determining the significance of the interaction between the elements of a transport system having a strong influence on traffic safety, Transport 28: 389-403. http://dx.doi.org/10.3846/16484142.2013.866980

Podviezko, A. 2012. Augmenting multicriteria decision aid methods by graphical and analytical reporting tools, in L. Niedrite, R. Strazdina, B. Wangler (Eds.). Workshops on Business Informatics Research (Vol. 106, pp. 236-251). Berlin, Heidelberg: Springer. http://dx.doi.org/10.1007/978-3-642-29231-6_19

Podviezko, A. 2015. Type of the Lithuanian financial system, Procedia Economics and Finance 23: 16351640. http://dx.doi.org/10.1016/S2212-5671(15)00378-0

Podviezko, A.; Podvezko, V. 2014. Absolute and relative evaluation of socio-economic objects based on multiple criteria decision making methods, Inzinerine Ekonomika-Engineering Economics 25(5): 522-529. http://dx.doi.org/10.5755/j01.ee.25.5.6624 
Popenkov, D. R. 2006. Tax potential of the Federation: evaluation and prediction on complex macroeconomic indicators. Vladivostok, Russia: Admiral Nevelsky Marine State University.

Saaty, T. L. 1980.The analytic hierarchy process. New York: McGraw Hill.

Schratzenstaller, M. 2011. Vom Steuerwettbewerb zur Steuerkoordinierung in der EU? Wirtschafts- und Sozialwissenschaftliches Institut, WSI-Mitteilungen 6: 304-313.

Shin, K. 1969. International differences in tax ratio, Review of Economics and Statics 51: 213-220. http://dx.doi.org/10.2307/1926733

Skackauskiene, I. 2013. Research on the dynamics of Lithuanian state revenue and preferences for expenditure allocation, Journal of Business Economics and Management 14 (4): 806-817. http://dx.doi.org/10.3846/16111699.2013.789451

Skackauskiene, I.; Tuncikiene, Z. 2012. The evaluation of the Lithuanian tax system reform, in 7th International Scientific Conference "Business and Management 2012". (pp. 749-759). Vilnius, Lithuania: Technika.

Stotsky, J. G.; WoldeMariam, A. 1997. Tax effort in sub-saharan Africa, IMF Working Paper 107: 1-57. http://dx.doi.org/10.5089/9781451852943.001

Savrina, B. 2013. Joint venture formation influencing factors within the aspect of economic policy implemented in Belarus from EU business prospective, Economics and Sociology 6(1): 28-45. http://dx.doi.org/10.14254/2071-789X.2013/6-1/3

Tamosaitiene, J.; Kaplinski, O. 2013. Strategic Environmental Assessment (SEA) of socio-economic systems: a systematic review, Technological and Economic Development of Economy 19(4): 661-674. http://dx.doi.org/10.3846/20294913.2013.862882

Tolstaya, O. V. 2010. Tax potential of the region and its development. Doctoral Dissertation. Moscow: Financial Academy of the Russian Federation.

Vylkova, E. S.; Pozov, I. A. 2013. Criteria affecting the tax status of the region, Journal of Legal and Economic Studies 4: 1-14.

Walia, K. 2013. An introduction to tax structure, International Journal of Computing and Business Research 4(2): 17-20.

Zavadskas ,E. K.; Vainiunas, P.; Turskis, Z.; Tamosaitiene, J. 2012. Multiple criteria decision support system for assessment of projects managers in construction, International Journal of Information Technology \& Decision Making 11(2): 501-520. http://dx.doi.org/10.1142/S0219622012400135

Lyudmila PARFENOVA. Doctor, Professor at the P.G. Demidov Yaroslavl State University and Dean at Economy Faculty of P.G. Demidov Yaroslavl State University. Author and co-author of more than 100 scientific articles and books. Research interests: international finances and European integration.

Andrey PUGACHEV. Postgraduate student at the P.G. Demidov Yaroslavl State University. He is an author and co-author of more 70 publications. Research interests: tax systems and tax potential of a region, investment policy.

Askoldas PODVIEZKO. Doctor, Associate Professor at the Institute of Economics, Mykolas Romeris University. He is an author and co-author of more 35 publications. Research interests: decision-making, expert systems, mathematical methods in modelling socio-economic, technological and engineering processes, hierarchical structuring of complex entities, sampling and forecasting models, simulation and stability mathematical models. 